\title{
TWO NEW ALIEN FERN TAXA FOR MADEIRA ISLAND (PORTUGAL)
}

\author{
João Pedro Ferreira*, Laura Cabral*, André Brazão*, \\ Pedro Nascimento* \& Miguel Menezes de Sequeira*
}

\begin{abstract}
The Madeira archipelago vascular flora includes 74 pteridophyte taxa. Of these, eight are exclusive endemics, eight are Macaronesian endemics, being the vast majority, 44, native and 14 referred as introduced taxa. The total number of alien vascular plant taxa is 401 (i.e. $33 \%$ of the total flora). The recent detection of several fully naturalized alien fern taxa is a process parallel to that observed in other groups of vascular plants. The occurrence of Pteris nipponica W.C. Shieh (syn. Pteris cretica L. var. albolineata Hooker) and Goniophlebium subauriculatum (Blume) C. Presl as new naturalized plants is recorded for the first time for the island of Madeira.
\end{abstract}

Keywords: alien, ferns, Goniophlebium, Madeira, Pteris, new records.

\author{
DOS NUEVOS TAXA DE HELECHOS EXÓTICOS
}

PARA LA ISLA DE MADEIRA (PORTUGAL)

\section{RESUMEN}

La flora vascular del archipiélago de Madeira incluye 74 taxones de pteridofitas. De ellos, ocho son endemismos exclusivos, otros ocho endemismos macaronésicos, siendo la gran mayoría, unos 44, especies nativas y 14 más son consideradas exóticas. El número total de taxones de plantas vasculares exóticas es de 401, lo que supone aproximadamente el 33\% del total de la flora. La reciente detección de muchas especies de helechos totalmente naturalizadas es paralela a la que ocurre con otros grupos de plantas vasculares. En este trabajo se registra por primera vez la presencia de Pteris nipponica W.C. Shieh (syn. Pteris cretica L. var. albolineata Hooker) y Goniophlebium subauriculatum (Blume) C. Presl como nuevas especies naturalizadas para la isla de Madeira.

Palabras Clave: especies exóticas, helechos, Goniophlebium, Madeira, Pteris, nuevos registros. 


\section{INTRODUCTION}

Madeira island ( $32^{\circ} 52^{\prime}$ and $32^{\circ} 38^{\prime} \mathrm{N}, 16^{\circ} 39$ and $\left.17^{\circ} 15^{\prime} \mathrm{W}\right)$, located in the eastern Atlantic $(978 \mathrm{~km}$ from mainland Portugal and $630 \mathrm{~km}$ from the west coast of Morocco), has an area of $741 \mathrm{~km}^{2}$ and is the more recent island of the Madeiran archipelago (5.6 Ma, Jardim and Menezes de Sequeira 2014). According to Jardim and Menezes de Sequeira (2008), a total of 74 pteridophyte taxa occur in the Madeira and Selvagens archipelagos, where 8 are exclusive endemics, 8 Macaronesian endemics, the majority (44) are native and 14 are introduced (according to Rumsey, pers. com., the actual numbers could be, 78 total taxa, 6 Madeiran endemics, and 9 Macaronesian endemics). Introduced vascular plant taxa contribute for $33 \%$ of 1204 taxa of vascular plants.

Comparing with the other Macaronesian archipelagos, Madeira has the higher number and diversity of native fern taxa, however, Azores has more fern taxa (83) than Madeira (Sánchez-Pinto et al. 2005; Silva et al. 2010; Jardim and Menezes de Sequeira 2008; Acebes Ginovés et al. 2010). Several factors can explain this diversity namely, island age, topography heterogeneity (a related factor), bioclimate and ecological diversity and probably by the lack of recent volcanic eruptions in the island of Madeira (Capelo et al. 2004; Ferrer-Castán and Vetaas 2005).

The recent identification of naturalized ornamental species corresponds to an increase in the total number of naturalized taxa that elucidates the current expansion of alien vascular plant taxa (e.g. Ferreira et al. 2011, Pupo-Correia and Menezes de Sequeira 2014, Jardim and Menezes de Sequeira 2015).

\section{MATERIAL AND METHODS}

Fieldwork took place in 2016 and 2017, recorded data included slope, altitude, number of individuals and plant community description. Collected specimens were included in the University of Madeira Herbarium. Taxonomical identification followed Gibby and Paul (1994), Derrick et al. (1987), Page and Bennel (1984), Hovenkamp and Miyam (2005), Nauman (1993), Nogueira (1998), RödlLinder (1990), Walker (1993) and Xing et al. (2013).

* Madeira Botanical Group (GBM), Faculty of Life Sciences, Universidade da Madeira, Funchal, Madeira, Portugal. Corresponding author: lauramariana97@hotmail.com.

** Madeira Botanical Group (GBM), Faculty of Life Sciences, Universidade da Madeira, Funchal, Portugal. InBio, Research Network in Biodiversity and Evolutionary Biology, CIBIO - Azores, Portugal. 


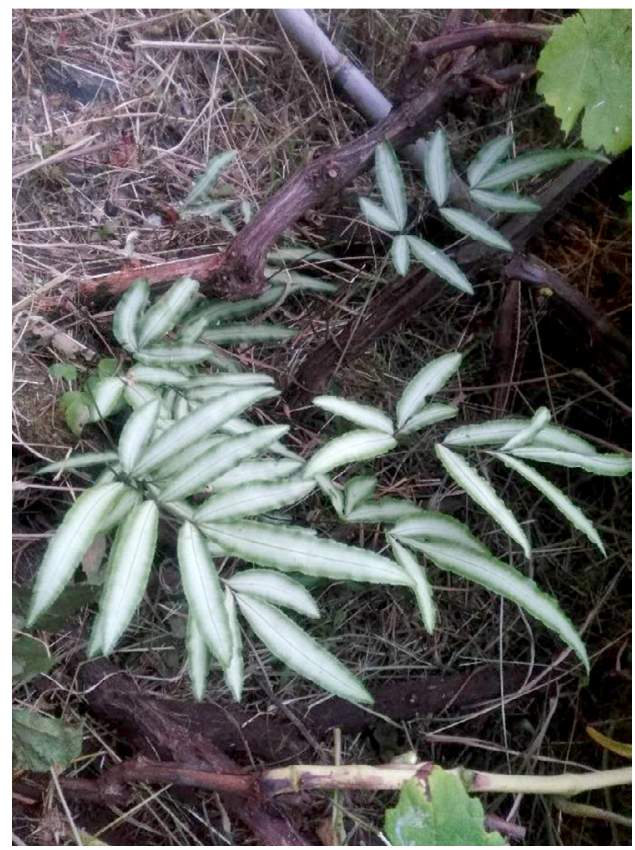

Figure 1. Pteris nipponica in Porto da Cruz.

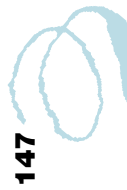

\section{RESULTS}

New taxa:

Pteris nipponica W.C. Shieh (syn. Pteris cretica L. var. albolineata Hooker) (Pteridaceae) (figure 1).

Portugal, Madeira, Calheta. Across a levada close to a pathway at an altitude of ca. 139 m, 01-VIII-2017, Luís Berimbau, LB42, UMad s/n (sub Pteris cretica L.).

Pteris nipponica, known as white-striped Cretan brake fern, is widely distributed due to its use as ornamental species (GISD 2010; Stace 2010). Although referred as pantropical its native range is unclear (GISD 2010; GBIF 2017a). According to Nogueira (1998) it grows on shady rock walls or steep slopes. In the Madeiran archipelago four species of genus Pteris L. (Pteridaceae) were so far recognized, $P$. vittata L., $P$. tremula R. Br. and $P$. multifida Poir. as alien species and Pteris incompleta Cav. as native (Gibby \& Paul 1994).

In Macaronesia, Pteris nipponica, referred as $P$. cretica var. albolineata, is found in the Azores (Sjögren 1973; Silva et al. 2010) and the Canarian archipelago (Kunkel 1971). In both archipelagos, Pteris nipponica escaped from cultivation as 
an ornamental plant (Kunkel 1971; Sjögren 1973). P. nipponica is an appreciated ornamental plant much commercialized all over the world (Page and Bennel 1984; GBIF 2017b).

Pteris nipponica is easily distinguished from other Madeiran Pteris taxa by having irregular and variously pinnate fronds (Gibby and Paul 1994). P. multifida is close to Pteris nipponica, but has much narrower segments on fertile fronds. Pteris nipponica can also be distinguished from $P$. multifida for having pinnae of mature fronds not decurrent, with a broad, white, central stripe, the main character that separates P. nipponica from P. multifida (Nauman 1993).

Dichotomous key based on Gibby and Paul 1994 and Nauman 1993

1. Fronds pinnate, pinnae simple.

Pteris vittata

1'. Fronds more divided 2

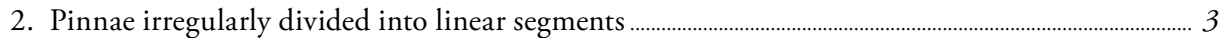

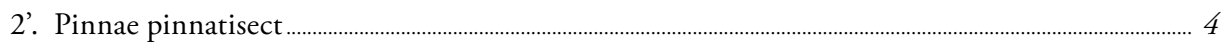

3. Pinnae of mature fronds decurrent to relatively broad-winged rachis in at least distal $1 / 2$ of frond, pinnae all green Pteris multifida

3'. Pinnae of mature leaves not decurrent to relatively broad-winged rachis or only terminal pinna decurrent on rachis, pinnae with broad, white, central stripe Pteris nipponica

4. Pinna segments contiguous, narrowly triangular, sori on pinna segment margins longer on basiscopic side than on acroscopic side. Pteris incompleta

4. Pinna segments decurrent, lanceolate; sori on pinna segment margins equal in length.

Pteris tremula

The potential impacts of $P$. nipponica as alien species are largely unknown. In Madeira, this species appears to be a sub spontaneous naturalized plant but, possibly, it will become very frequent on walls and rocks everywhere in the island, as happened for $P$. vittata and $P$. tremula (Vieira 2002). One population of $P$. nipponica, fully naturalized in rocky habitats, was found in Calheta below $250 \mathrm{~m}$, and it was also observed in Porto da Cruz (Machico, figure 1). Populations included a reduced number of individuals, sometimes corresponding to one individual.

Goniophlebium subauriculatum (Blume) C. Presl, Tent. (Polypodiaceae) (figure 2).

Portugal, Madeira, Funchal, Madalenas, Caminho de Santo António. Rupícola, na margem de um caminho, alt. ca. 193 m. 01-VIII-2016. André Brazão, AB62. UMad s/n. (figure 2).

Goniophlebium subauriculatum, commonly known as Caterpillar Fern, has a native range that includes NE India, SW China, Burma, Laos, Vietnam, throughout Malesia to Australia (Lindsay and Middleton 2012; Hassler 2019). Although widely cultivated in many European gardens (Lowe 1856; Page and Bennel 1984) there is no reference to the naturalization of G. subauriculatum in Europe (Derrick et al. 1987). Its occurrence as naturalized in Madeira Island constitutes the first naturalization 


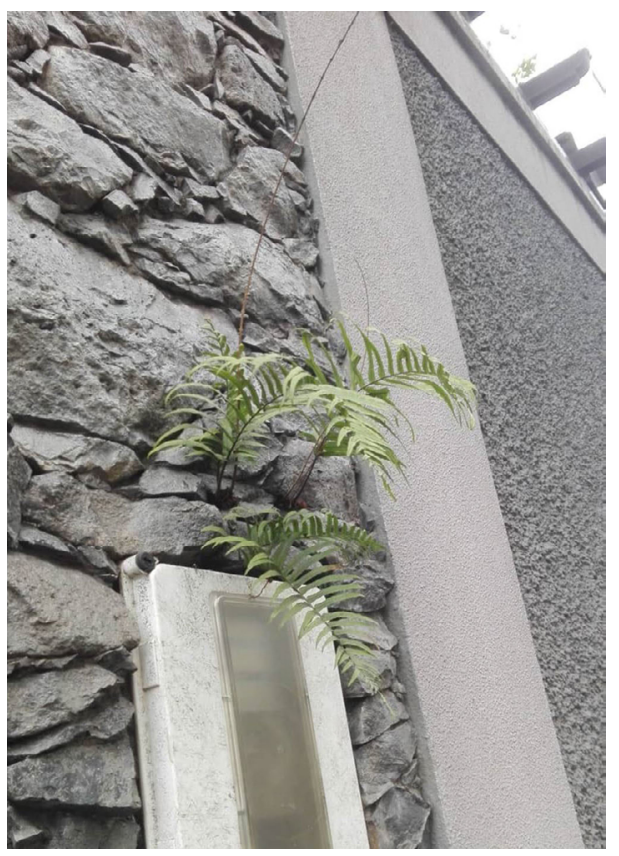

Figure 2. Goniophlebium subauriculatum in Funchal, Madalenas, Caminho de Santo António.

reference for Macaronesia and Europe both for genus and species (Jardim and Menezes de Sequeira 2008; Silva et al. 2010; Acebes Ginovés et al. 2009; SánchezPinto et al. 2005; Acebes Ginovés et al. 2010).

Goniophlebium subauriculatum can be easily identified taking in account it is very long, up to $129 \mathrm{~cm}$, slender simply-pinnate fronds and weeping habit. The fronds have a pendulous habit, are bright green in colour, lanceolate with pinnae long, narrow and lanceolate to acuminate in shape, articulated with the rachis, serrate on the edges, and sub-auriculate at the base. It has a pubescent rachis, a brown stipe articulated with a creeping and densely scaly rhizome. Another diagnostic character is its uniserial yellowish-brown sori, immersed in the frond, forming raised protuberances on its adaxial surface (Lowe 1856; Rödl-Linder 1990, F. Rumsey, pers. Com.).

Goniophlebium subauriculatum was found establishing fully naturalized, selfperpetuating populations, clearly dispersing away from the place of introduction. Observations support a successful sexual reproduction and therefore it may colonize new areas, mainly in rock or wall crevices, forming communities with other alien ferns such as Pteris vittata L. and Nephrolepis cordifolia (L.) C. Presl. It was found so far restricted to low altitudes (below $170 \mathrm{~m}$ a.s.l.) in Santo António (Funchal), forming small populations occurring both in shady or exposed rocky habitats. Naturalized individuals were found elsewhere in Funchal (S. Roque). 


\section{DISCUSSION}

Both Pteris nipponica and Goniophlebium subauriculatum appear to form selfreplacing populations by recruitment from spores or ramets capable of independent growth, without direct human intervention, and both should be considered as naturalized species (Pyšek et al. 2004). However, P. nipponica naturalization process is clearly more advanced than the one observed for G. subauriculatum mainly due to its distribution range with populations established far away from each other without cultivated specimens observed nearby, while G. subauriculatum has, so far, a restricted distribution.

The potential impacts of these alien species are unknown. However, other alien ferns are steadily expanding their ranges and are known to be displacing native species (in Madeira Adiantum raddianum C. Presl is a clear example), with catastrophic consequences for both the environment and human welfare (Robinson $e t$ al. 2010). More than $50 \%$ of the alien taxa correspond to plants originally introduced as ornamental garden plants and landscaping (Li et al. 2006). Both Pteris nipponica and Goniophlebium subauriculatum correspond to plants often used in gardens and nurseries (Lowe 1856; Page and Bennel 1984; GISD 2010), and their naturalization further stress's the urgent need for an efficient management and control of species used as ornamental plants.

\section{ACKNOWLEDGMENTS}

The authors are grateful to the IFCN (Instituto das Florestas e Conservação da Natureza, IP-RAM) for the collecting permit (n. ${ }^{\circ}$ 05/IFCN/2017 - Flo Mad). The authors also want to acknowledge Fred Rumsey and an anonymous reviewer for their valuable comments.

\section{AUTHORS' CONTRIBUTION}

Introduction: J.F.

Field work: J.F., L.C., P.N., A.B.

Methodologies: J.F., L.C., P.N., A.B., M.S.

Results and Discussion: J.F., L.C P.N., A.B., M.S.

Review and edition of the final draft: M.S., L.C. 


\section{REFERENCES}

Acebés Ginovés, J.A., León Arencibia, C.M., Navarro, M., Del Arco, M.J., García-Gallo, A., Pérez de Paz, P.L., Rodríguez Delgado, O., Martín Osorio, V.E. and Wildpret, W. 2010. Pteridophyta, Spermatophyta. In: Arechavaleta, M., Rodríguez, S., Zurita, N. and García, A. (eds.) Lista de Especies Silvestres de Canarias: Hongos, Plantas y Animales terrestres, 2010. Consejería de Política Territorial y Medio Ambiente, Gobierno de Canarias pp. 119-172.

Capelo, J., Menezes de Sequeira, M., Jardim, R. and Costa, J.C. 2004. Guia da excursão geobotânica dos V Encontros ALFA 2004 à ilha da Madeira. In: Capelo, J. (ed.) A paisagem vegetal da ilha da Madeira. Quercetea 6: 4-54.

Christenhusz, M. and Von Raab-Straube, E. 2013. Polypodiopsida. Euro+Med Plantbase - the information resource for Euro-Mediterranean plant diversity; [cited 2018 Sep 4]. Available from: http://ww2.bgbm.org/europlusmed/.

Derrick, L.N., Jermy, A.C. and Paul, A.M. 1987. Checklist of European Pteridophytes. Sommerfeltia 6: I-XX + 1-94.

Ferreira, Z., Álvarez, I., Jardim, R. and Menezes de Sequeira, M. 2011. Andryala integrifolia L. (Asteraceae), a new introduced species for the island of Madeira (Portugal). Silva Lusit. 19: 114-125.

Ferrer-Castán, D. and Vetaas, O.R. 2005. Pteridophyte richness, climate and topography in the Iberian Peninsula: comparing spatial and nonspatial models of richness patterns. Global Ecol. Biogeogr. 14: 155-165.

GBIF. 2017a. Pteris cretica L.; [cited 2019 Mar 14]. Available from: https://goo.gl/kEz4qe.

GBIF. 2017b. Pteris cretica var. albolineata Hook; [cited 2019 Mar 14]. Available from: https://goo. gl/kvkPLw.

Gibby, M. and Paul, A.M. 1994. VII. Pteridaceae. In: Press, J.R. and Short, M.J. (eds.) Flora of Madeira. London: The Natural History Museum pp. 36-37.

GISD. 2010. Pteris cretica; [Internet]. [cited 2019 Mar 14]. Available from: https://goo.gl/TQ5RGV.

HassLer, M. 2019. World Ferns: Checklist of ferns and lycophytes of the world (version Nov 2018). In: Roskov, Y., Ower, G., Orrell, T., Nicolson, D., Bailly, N., Kirk, P.M., Bourgoin, T., DeWalt, R.E., Decock, W., van Nieukerken, E., Zarucchi, J. and Penev, L. (eds.) Species 2000 \& ITIS Catalogue of Life, 2019 Annual Checklist. Leiden, The Netherlands: Naturalis.

Jardim, R. and Menezes de Sequeira, M. 2015. New neophytes for the Madeira Island (Portugal). Silva Lusit. 23: 106-110.

Jardim, R. and Menezes de Sequeira, M. 2008. As plantas vasculares (Pteridophyta e Spermatophyta) dos arquipélagos da Madeira e Selvagens In: Borges, P., Abreu, C., Franquinho Aguiar, A.M., Carvalho, P., Jardim, R., Melo, I., Oliveira, P., Sérgio, C., Serrano, A.R.M. and Vieira, P. (eds.) Listagem dos fungos, flora e fauna terrestres dos arquipélagos da Madeira e Selvagens. Funchal \& Angra do Heroísmo: Direcçáo Regional do Ambiente da Madeira and Universidade dos Açores pp. 157-209.

Jardim, R. and Menezes de Sequeira, M. 2014. Contributions to the knowledge of the vascular flora of Porto Santo island (Madeira archipelago, Portugal). Silva Lusit. 22: 237-256.

Kunkel, G. 1971. Lista Revisada de los Pteridofitos de las Islas Canarias. Cuad. Bot. Canar. 13: 21-46. 
Li, Y., Cheng, Z., Smith, W., Ellis, D., Chen, Y., Lu, L., Mcavoy, R.J., Pei, Y., Deng, W., Thammina, C., Zheng, X., Duan, H., Luo, K. and Zhao, D. 2006. Problems and Challenges of Invasive Ornamental Plants and Molecular Tools to Control their Spread, J. Crop. Improv. 17: 279-301.

Lindsay, S. and Middleton, D. 2012. Goniophlebium subauriculatum (Blume) C.Presl; [cited 2019 Mar 17]. Available from: https://goo.gl/i4JaXD.

Lowe, E.J. 1856. Ferns: British and Exotic. London: Groombridge and Sons 163 pp.

Nauman, C.E. 1993. Pteris. In: Morin, N.R. (ed.). Flora of North America: Pteridophytes and Gymnosperms. New York and Oxford: Flora of North America Editorial Committee pp. 132-135.

Nogueira, I. 1998. Pteris L. In: Castrovejo, S., Aedo, C., Laínz, M., Muñoz Garmendia, F., Nieto Feliner, G., Paiva, J. and Benedí, C. (eds.). Flora Ibérica. Madrid: Real Jardín Botánico pp. 57-60.

Page, C.N. and Bennel, F.M. 1984. Goniophlebium. In: Walters, S. and Cullen, J. (eds.). European Garden Flora: A Manual for the Identification of Plants Cultivated in Europe, Both Out-ofDoors and Under Glass. Cambridge: The European Garden Flora Editorial Committee 43 pp.

Press, J. and Short, M. 1994. Flora of Madeira. London: The Natural History Museum 590 pp.

Pupo-Correia, A. and Menezes de Sequeira, M. 2014. Billardiera heterophylla (Lindl.) L. Cayzer and Crisp (Pittosporaceae) as naturalised plant in Madeira Island (Portugal). Silva Lusit. 22: 27-33.

Pyšek, P., Richardson, D.M., Rejmánek, M., Webster, G.L., Williamson, M. and Kirschner, J. 2004. Alien Plants in Checklists and Floras: Towards Better Communication between Taxonomists and Ecologists. Taxon 53: 131-143.

Robinson, R., Sheffield, E. and Sharpe, J. (2010). Problem ferns: Their impact and management. Fern Ecology 255-322.

RöDl-Linder, G. 1990. A monograph of the fern genus Goniophlebium (Polypodiaceae). Blumea 34: $277-423$.

Sánchez-Pinto, L., Rodríguez, M.L., Rodríguez. S., Martín, K., Cabrera, A. and Marrero, M. 2005. Pteridophyta and Spermatophyta In: Arechavaleta, M., Zurita, N., Marrero, M.C. and Martín Esquivel, J. (eds.) Lista Preliminar de Especies Silvestres de Cabo Verde (Hongos, Plantas y Animales Terrestres). Consejería del Medio Ambiente y Ordenación Territorial, Gobierno de Canarias pp. 38-57.

Silva, L., Pinto, N., Press, B., Rumsay, F., Carine, M., Henderson, S. and Sjögren, E. 2010. Lista das plantas vasculares (Pteridophyta e Spermatophyta) In: Borges, P.A.V., Cunha, R., Gabriel, R., Martins, A.F., Silva, L. and Vieira, V. (eds.). Listagem da fauna (Mollusca e Arthropoda) e flora (Bryophyta, Pteridophyta e Spermatophyta) terrestres dos Açores. Horta, Angra do Heroísmo and Ponta Delgada: Direcção Regional do Ambiente and Universidade dos Açores pp. 130-155.

Sjögren, E. 1973. Vascular Plants New to the Azores and to Individual Islands in the Archiphelago. Boletim do Museu Municipal do Funchal 27: 94-120.

Stace, C. 2010. Pteridaceae-Ribbon Fern family. In: Stace, C. (ed.). New Flora of the British Isles. Cambridge University Press 19 pp.

Vieira, R.M. 2002. Flora da Madeira: plantas vasculares naturalizadas no arquipélago da Madeira. Câmara Municipal do Funchal 288 pp. 
Walker, T.G. 1993. Pteris. In: Tutin, T., Burces, N.A., Chater, A.O., Edmondson, J.R., Heywood, V.H., Moore, D.M., Valentine, D.H., Walters, S.M. and Webb, D.A. (eds.). Flora Europaea. Cambridge University Press 14 pp.

Xing, F.W., Wang, F.G. and Hovenkamp, P.H. 2013. Nephrolepidaceae. In: Wu, Z.Y., Raven, P.H. and Hong, D.Y. (eds.). Flora of China. Beijing: Science Press and St. Louis: Missouri Botanical Garden Press pp. 727-729. 
